\title{
GEOGRAPHICAL CLINE OF ALLELE FREQUENCY OF GROUP-SPECIFIC COMPONENT (GC) IN THE JAPANESE POPULATIONS: AN ANALYSIS OF DATA OBTAINED BY IMMUNOELECTROPHORESIS
}

\author{
Isao Yuasa, ${ }^{1}$ Yukio Saneshige, ${ }^{2, *}$ and Kichiro OKADA ${ }^{1}$ \\ ${ }^{1}$ Department of Legal Medicine, Tottori University School of Medicine, \\ Yonago 683, Japan \\ 2Department of Medical Technology, Tottori University College of \\ Medical Care Technology, Yonago 683, Japan
}

\begin{abstract}
Summary An analysis of data on GC allele frequency obtained by immuncelectrophoresis adduced an evidence for the existence of geographical cline in the Japanese populations. The $G C^{*} 2$ frequencies proved to be increasing gradually from north to south in Japan: the cline will be explicable by gene flow but not by natural selection.
\end{abstract}

\section{INTRODUCTION}

Hirschfeld (1959) identified the genetic polymorphism of GC: three phenotypes of GC 1, 2-1 and 2 determinable by two codominant alleles of $G C^{*} l$ and $G C^{*} 2$ are observed together with several variant phenotypes (Johnson et al., 1975) with the aid of immunoelectrophoresis and immunofixation electrophoresis. Data on the racial and geographical variations of GC allele frequencies have been accumulated and analyzed (Walter and Steegmüller, 1969; Mourant et al., 1975, 1976).

In Japan, geographical clines of the allele frequencies have so far been clarified as to only ABO and GPT (Nei and Imaizumi, 1966; Fujita et al., 1978; Ishimoto and Kuwata, 1974). According to Omoto (1978), Aoki's attempt to demonstrate a cline of GC failed. The used data, compiled by Omoto (1975a), must have lacked those from the Western Japan.

In this study the existence of the geographical cline of $\mathrm{GC}$ allele frequencies in Japan is demonstrated with recently published data supplemented, and furthermore the factors of occurrence of cline are discussed.

\section{MATERIALS AND METHODS}

The data on the GC allele frequency in the Japanese and the neighboring popu-

Received April 22, 1983

* Present address: Auckland Blood Transfusion Service, Auckland, New Zealand. 
lations obtained by immunoelectrophoresis were collected from the widely scattered literature.

The existence of geographical cline was demonstrated as was carried out by Nei and Imaizumi (1966) and Fujita et al. (1978) for ABO blood group system. The relationship was examined between the GC allele frequency and distance from Aomori, northernmost part of Honshu Island, to each prefectural capital of populations.

\section{RESULTS AND DISCUSSION}

Table 1 summarizes the distribution of $G C^{*} 2$ frequency in the Japanese and the neighboring populations. Figure 1 shows the places where samples have been obtained for the examination of GC polymorphism.

The $G C^{*} 2$ frequencies among the Japanese living in main islands of Japan (so-called Wajin) vary from 0.225 in Miyagi to 0.288 in Miyazaki with an average of 0.258 . A test is made for homogeneity of the gene frequencies among 12 popu-

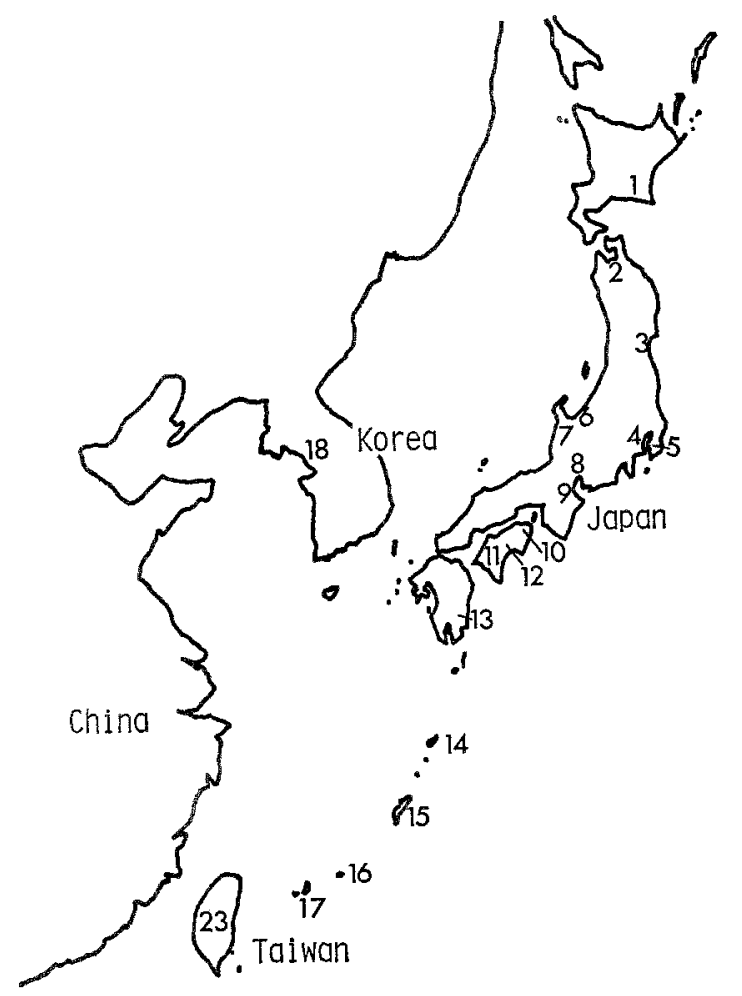

Fig. 1. Map of Japan and the neighboring countries. The numbers correspond to those in Table 1. 
Table 1. $G C^{*} 2$ frequencies in the Japanese and neighboring populations.

\begin{tabular}{|c|c|c|c|c|c|}
\hline \multicolumn{2}{|c|}{ Populations } & Distance a & $\begin{array}{l}\text { Number } \\
\text { examined }\end{array}$ & $\begin{array}{c}G C^{*} 2 \\
\text { frequencies }\end{array}$ & References \\
\hline \multicolumn{6}{|c|}{ Japanese } \\
\hline 1 & Ainu & & 467 & .250 & Omoto and Harada (1972) \\
\hline 2 & Aomori & 0.00 & 632 & .252 & Kita and Murakami (1973) \\
\hline 3 & Miyagi & 0.39 & 570 & .225 & Kudo (1973) \\
\hline $4 a$ & Tokyo & 0.74 & 500 & .227 & Omoto et al. (1964) \\
\hline $4 b$ & Tokyo & 0.74 & 376 & .225 & Ishimoto et al. (1967) \\
\hline $4 \mathrm{c}$ & Tokyo & 0.74 & 204 & .260 & Ohyuki and Ikemoto (1967) \\
\hline $4 \mathrm{~d}$ & Tokyo & 0.74 & 316 & .255 & Suzuki et al. (1968) \\
\hline $4 \mathrm{e}$ & Tokyo & 0.74 & 566 & .261 & Ikemoto et al. (1970) \\
\hline $4 f$ & Tokyo & 0.74 & 1,962 & .244 & combined \\
\hline 5 & Chiba & 0.78 & 1,577 & .248 & Ishimoto et al. (1967) \\
\hline 6 & Toyama & 0.71 & 112 & .259 & Ohyuki and Ikemoto (1967) \\
\hline 7 & Hokuriku & 0.77 & 504 & .246 & Hayashi et al. (1978) \\
\hline 8 & Gifu & 1.14 & 1,021 & .262 & Suyama and Uchida (1969) \\
\hline 9 & Mie & 1.17 & 217 & .263 & Yada et al. (1966) \\
\hline 10 & Tokushima & 1.58 & 598 & .268 & Yada et al. (1974) \\
\hline 11 & Ehime & 1. 70 & 160 & .266 & Shinomiya et al. (1978) \\
\hline 12 & Kochi & 1.66 & 1,089 & .284 & Ishizu et al. (1983) \\
\hline 13 & Miyazaki & 2.19 & 341 & .288 & Sugita and Takahama (1978) \\
\hline 14 & Amami Ohshima & & 234 & .301 & Omoto and Harada (1967) \\
\hline $15 \mathrm{a}$ & Okinawa & & 527 & .288 & Nakajima and Ohkura (1971) \\
\hline $15 \mathrm{~b}$ & Naha & & 204 & .306 & Omoto et al. (1973) \\
\hline $16 \mathrm{a}$ & Miyako-jima & & 351 & .249 & Nakajima and Ohkura (1971) \\
\hline $16 \mathrm{~b}$ & Miyako-jima & & 163 & .310 & Waki (1972) \\
\hline 17 & Yaeyama shoto & & 84 & .369 & Waki (1972) \\
\hline \multicolumn{6}{|c|}{ Korean } \\
\hline $18 \mathrm{a}$ & Seoul & & 116 & .241 & Omoto et al. (1964) \\
\hline $18 b$ & Seoul & & 122 & .303 & Kitchin and Bearn (1964) \\
\hline 19 & Kyungsan & & 115 & .278 & Ohkura et al. (1979) \\
\hline 20 & Kannung & & 114 & .263 & Miyashita et al. (1980) \\
\hline \multicolumn{6}{|c|}{ Chinese } \\
\hline 21 & North China & & 88 & .312 & Nakajima and Ohkura (1971) \\
\hline 22 & South China & & 100 & .275 & Nakajima and Ohkura (1971) \\
\hline \multicolumn{6}{|c|}{ Taiwanese } \\
\hline 23 & Taiwan & & 100 & .215 & Nakajima and Ohkura (1971) \\
\hline
\end{tabular}

a From Aomori $(1,000 \mathrm{~km})$. 
lations with 5 data from Tokyo combined. The results show that there is a statistically significant heterogeneity $\left(\chi^{2}=24.4994, \mathrm{df}=11,0.02>\mathrm{p}>0.01\right)$. It is also observed that the frequencies are lower in Eastern Japan than in Western Japan. The relationships between the $G C^{*} 2$ frequency in each population and the distance fromAomori are plotted in Fig. 2. The correlation coefficient between the frequency and the distance is $0.83068(\mathrm{t}=4.7182, \mathrm{df}=10, \mathrm{p}<0.001)$, and the regression equation of the frequency $(y)$ on the distance $(x)$ is $y=0.0232 x+0.2339$. These results show that the geographical clines of GC allele frequencies exist in the Japanese populations, namely the $G C^{*} 2$ frequencies increase gradually towards southern localities.

The $G C^{*} 2$ frequencies among the Japanese living in Ryukyu Islands (so-called Ryukuan) range in between 0.249 and 0.369 , and are apparently higher than those among Wajin (Omoto et al., 1973). It appears that the above-mentioned clines extend to Ryukyuan populations. The neighboring populations including the Koreans and the Chinese show rather higher $G C^{*} 2$ frequencies on the whole. The cline found in the Wajin may also reach the Korean and the Chinese populations along other routes.

On the other hand, GC is known to be a carrier protein of vitamin D (Daiger et al., 1975). Walter and Steegmüller (1969) have reported that $G C^{*} 2$ frequencies tend to decrease from north to south in the Old World. Mourant et al. (1976) have shown that $G C^{*} 2$ frequencies are low in sunny climates and high in dull climates, and have suggested that the occurrence of such a difference is due to natural selection related to efficiency in fixing vitamin D. A geographical decrease in the $G C^{*} 2$

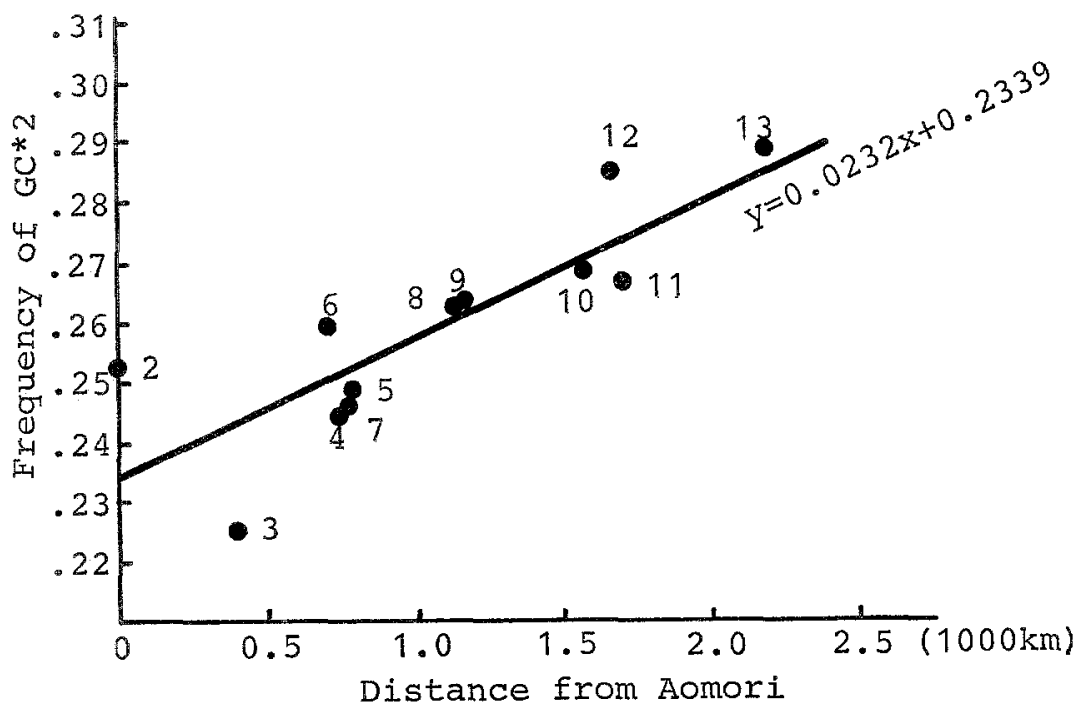

Fig. 2. Gradient of $G C^{*} 2$ allele frequency. 
frequency from north to sourth in the Chinese populations (Nakajima and Ohkura, 1971 ) is well-explicable by the above hypothesis. Another explanation may be given that such a cline was formed by gene flow in past spreads of populations acquiring high $G C^{*} 2$ frequency in dull climates.

The findings that in Japan the $G C^{*} 2$ frequencies increase gradually towards sunny climates are not explicable by the natural selection. It should be thought that the occurrence of the cline directly proportioned to the mean intensity of solar radiation is due to the gene flow. Japan Islands are a branch of such migrations. This notion may be supported by the high $G C^{*} 2$ frequencies in the neighboring populations and by the slightly low frequency in the Ainu population, which remains relatively unaffected by the genetic component of the "later" Mongoloid populations due to their geographically peripheral position (Omoto, 1975b). Eskimos, acquiring high adaptability to cold, have high $G C^{*} 2$ frequencies (Mourant et al., 1975).

Recently Constans and Viau (1977) succeeded in subtyping the common $G C^{*} 1$ allele into two subtype alleles of $G C^{*} 1 F$ and $G C^{*} 1 S$ with the aid of polyacrylamide gel isoelectric focusing followed by immunofixation with anti-GC serum. This technique provides us with further informations of the Japanese and the neighboring populations. An analysis of these data is in progress (Yuasa et al., 1983).

Acknowledgment We are grateful to Ms. T. Yamaoka for her clerical assistance.

\section{REFERENCES}

Constans, J., and Viau, M. 1977. Group-specific component: evidence for two subtypes of the $\mathrm{Gc}^{1}$ gene. Science 198: 1070-1071.

Daiger, E.I., Schanfield, M.S., and Cavalli-Sforza, L.L. 1975. Group-specific component (Gc) proteins bind vitamin D and 25-hydroxyvitamin D. Proc. Natl. Acad. Sci. USA. 72: 20762080.

Fujita, Y., Tanimura, M., and Tanaka, K. 1978. The distribution of the ABO blood groups in Japan. Jpn. J. Human Genet. 23: 63-109.

Hayashi, K., Oguchi, M., Nakashima, K., and Nanikawa, R. 1978. The distribution of Hp, Gc, and ESD in the Hokuriku districts and the identification of these phenotypes in bloodstains J. Juzen Med. Soc. 87: 409-414 (in Japanese).

Hirschfeld, J. 1969. Immune-electrophoretic demonstration of qualitative differences in human sera and their relation to the haptoglobins. Acta Pathol. Microbiol. Scand. 47: 160-168.

Ikemoto, S., Kompa, R., and Mukoyama, H. 1970. Genetical studies of group-specific component (Gc) system. (1) $\mathrm{Gc}$ types of $\mathrm{ABO}$ blood group variants and distribution of $\mathrm{Gc}$ types of Japanese in Tokyo metropolis and Hachijo island. Natl. Res. Inst. Police Sci. 23: 192-196 (in Japanese).

Ishimoto, G., and Kuwata, M. 1974. Red cell glutamic-pyruvic transaminase polymorphism in Japanese populations. Jpn. J. Human Genet. 18: 373-377.

Ishimoto, G., Uemura, K., Toyomasu, T., and Watanabe, K. 1967. Population studies of serum protein variations in the Japanese. J. Anthropol. Soc. Nippon 75: 43-51 (in Japanese).

Ishizu, H., Shogano, N., Yamamoto, Y., and Okamura, K. 1983. Distribution of Ge types in Kochi prefecture. Acta Crim. Japon. 49: 1-4. 
Johnson, A.M., Cleve, H., and Aiper, C. 1975. Variants of the group-specific component system as demonstrated by immunofixation electrophoresis. Report of a new variant, Gc Boston (Gc B). Am. J. Hum. Genet. 27: 728-736.

Kita, T., and Murakami, S. 1973. Immunological studies on Gc system. Jpn. J. Legal Med. 27: 443 (in Japanese).

Kitchin, F.D. and Bearn, A.G. 1964. Distribution of serum group-specific components (Gc) in Afganistan, Korean, Nigerian and Israeli populations. Nature 202: 827-828.

Kudo, T. 1973. Cited by Omoto (1975a).

Miyashita, T., Ohkura, K., Hasekura, H., Nakamura, H., Hara, M., Kang, Y.S., and Lee, C.C. 1980. The distribution of polymorphic traits in Kannung, Korea. Jpn. J. Human Genet. 25: 141.

Mourant, A.E., Kopec, A.C., and Domaniewska-Sobczak, K. 1975. The Distribution of the Human Blood Groups and Other Polymorphisms, 2nd ed., pp. 686-695, Oxford Univ. Press, London.

Mourant, A.E., Tills, D., and Domaniewska-Sobczak, K. 1976. Sunshine and the geographical distribution of the alleles of the Gc system of plasma proteins. Hum. Genet. 33: 307-314.

Nakajima, H., and Ohkura, K. 1971. The distribution of several serological and biochemical traits in East Asia. III. The distribution of gammaglobulin ( $\mathrm{Gm} \mathrm{[1],} \mathrm{Gm} \mathrm{[2],} \mathrm{Gm} \mathrm{[5]} \mathrm{and} \mathrm{Inv} \mathrm{[1])}$ and Gc groups in Taiwan and Ryukyu. Hum. Hered. 21: 362-370.

Nei, M., and Imaizumi, Y., 1966. Genetic structure of human populations. I. Local differentiation of blood group gene frequencies in Japan. Heredity 21: 9-35.

Ohkura, K., Miyashita, T., Hasekura, H., Kang, Y.S., and Lee, C.C. 1979. The distribution of polymorphic traits in Korea. Jpn. J. Human Genet. 24: 213-214.

Ohyuki, Y., and Ikemoto, S. 1967. The Gc serum groups in the Japanese population in Tokyo and Toyama prefecture. Igaku to Seibutsugaku 74: 145-148 (in Japanese).

Omoto, K. 1975a. Serum protein groups. In JIBP Synthesis: Human Adaptability, Vol. 2, Anthropological and Genetic Studies on the Japanese, Watanabe, S., Kondo, S., and Matsunaga, E., eds., Univ. of Tokyo Press, Tokyo, pp. 141-162.

Omoto, K. 1975b. Genetic affinities of the Ainu as assessed from data on polymorphic traits. In JIBP Synthesis: Human Adaptability, Vol. 2, Anthropological and Genetic Studies on the Japanese, Watanabe, S., Kondo, S., and Matsunaga, E., eds., Univ. of Tokyo Press, Tokyo, pp. 296-303.

Omoto, K. 1978. Genetic polymorphisms in the Japanese (in Japanese, translated by the authors). In Jinruigaku Koza (Anthropology), Vol. 6, The Japanese II, Ikeda, J., ed., Yuzankaku Shuppan, Tokyo, pp. 217-263.

Omoto, K., and Harada, S. 1967. Investigations on some genetical traits among inhabitants of Amami Ohshima island. Proc. Meet. Anthropol. Soc. Nippon \& Jpn. Soc. Ethnol., 22nd Sess. (1967) 22: $55-57$ (in Japanse).

Omoto, K., and Harada, S. 1972. The distribution of polymorphic traits in the Hidaka Ainu. II. Red cell enzyme and serum protein groups. J. Fac. Sci. Univ. Tokyo V 4: 171-211.

Omoto, K., Ishizaki, K., Harada, S., Akaishi, S., Kudo, T., and Takahashi, K. 1973. The distribution of serum protein and red cell enzyme types among blood donors of Okinawa Is., the Ryukyus. J. Anthropol. Soc. Nippon 81: 159-173.

Omoto, K., Schwarzfischer, F., und Ziegelmayer, G. 1964. Zur Allelenhäufigkeit des Gc-systems bei Asiatischen und europäischen Population. Z, Biol. 114: 290-298.

Shinomiya, K., Shinomiya, T., and Kimura, H. 1978. Essai de détermination simultanée du type haptoglobinique et du type $\mathrm{d}^{\prime} \alpha_{2}-\mathrm{Gc}$ globuline des groupe sériques par immunoelectrophorèse sur gélose. Jpn. $J_{0}$ Legal Med: 32: 215-223.

Sugita, H., and Takahama, K. 1978. Studies on the distribution of Gc types in Miyazaki district. Acta Crim. Japon. 44: 52-53. 
Suyama, H., and Uchida, H. 1969. The Gc types in the Japanese. Hum. Hered, 19: 74-76.

Suzuki, K., Ikemoto, S., Ochiai, M., Tsuchihashi, Y., and Suzuki, H. 1968. Gc-groups in a Japanese population in Tokyo metropolis. Bull. Tokyo Dent. Coll. 9: 183-188.

Waki, K. 1972. The distribution of the polymorphic groups of blood, serum protein and red cell enzyme among the inhabitants in Miyako and Yaeyama Islands, Okinawa. J. Osaka Med. Coll. 31: 1-23.

Walter, H., and Steegmüller, H. 1969. Studies on the geographical and racial distribution of the $\mathrm{Hp}$ and Gc polymorphisms. Hum. Hered. 19: 209-221.

Yada, S., Okane, M., and Sano, Y. 1966. Distribution of the Gc serum group in a population in Mie prefecture. Jpn. J. Legal Med. 20: 368 (in Japanese).

Yada, S., Tsugawa, N., Kido, A., and Sawada, H. 1974. Distribution of Hp and Gc groups in Tokushima prefecture. $J_{p n} . J$. Legal Med. $28: 256$ (in Japanese).

Yuasa, I., Suenaga, K., Ito, K., Gotoh, Y., and Okada, K. 1983. Distribution of GC polymorphism and geographical cline of GC allele frequency in the Japanese populations. 67th Conf. Medico-Legal Soc. Jpn., Osaka, April 1-3, 1983.

Vol. 28, No. 4, 1983 